\title{
The impacts of weather on tourist travel
}

\author{
Abstract \\ Interest in the interactions between climate, weather and tourism has increased markedly in \\ the last decade in response to climate change concerns; however, there is little empirical \\ research on how tourists respond to the weather conditions they encounter. Thus, in this paper \\ we examine the impact of the weather on a sample of international tourists visiting New \\ Zealand during the 2009-10 summer season. Based on weather-related changes made to \\ tourists' travel routes, the timing of their travel and activity participation whilst in New \\ Zealand, respondents were segmented into three groups: those with 'no travel changes' \\ during their trip, 'some travel changes' and 'substantial travel changes' to their trip. The \\ results show a generally high level of changes made to trips, particularly in the less settled \\ early summer season, and an interesting link with satisfaction. The research provides an \\ empirical basis for a framework that would facilitate further research into the adaptive \\ capacity of tourists towards climate variability and change.
}

\section{Keywords}

Weather, travel changes, adaptive capacity, satisfaction, tourist behaviour

Cite as follows: Becken, S. \& Wilson, J. (2013). The impacts of weather on tourist travel. Tourism Geographies DOI: 10.1080/14616688.2012.762541. 


\section{Introduction}

Climate and weather are key ingredients of a destination's geography: they influence tourist flows, have significant on-site impacts on the tourism resource base and influence tourists' activity participation, satisfaction and safety. Therefore, considerable attention has been paid to climate as a destination attribute (Hu \& Ritchie, 1993), for example in relation to destination image construction (Pike, 2002) and the development of advertising materials (Gómez Martín, 2005). The relevance of climate and weather has also been analysed in the context of destination choice and timing of travel (Hamilton \& Lau, 2005, Hadwen et al., 2011) and the relative changes in climatic conditions in tourists' home countries (RosselloNadal et al., 2011). Interest in the interactions between climate, weather and tourism has increased markedly in the last decade in response to climate change concerns. Changes in destination attractiveness, both in relation to climatic parameters (Giles \& Perry, 1998; Hein et al., 2009; Maddison, 2001) and climate change induced environmental changes (Scott et al., 2008a), have been examined for different climate change scenarios.

Climate and weather denote different temporal scales of the same phenomenon (i.e. climate is the average weather) and are of interest to tourists at different times in their travel. Climate, for example, is most relevant in trip-planning stages, whereas weather (and weather forecasts) becomes more important during the trip (Scott \& Lemieux, 2010). Several studies have attempted to measure the optimal climatic conditions for particular tourist activities through the creation of climate-recreation indices (e.g. Morgan et al., 2000; Mieczkowski, 1985; Yu et al., 2009). However, fewer studies have considered the immediate impacts of the weather on tourists' travel behaviour and experiences once they are in situ. The weather acts as a facilitator that makes tourism activities possible and enjoyable (Gómez Martin, 2005), or conversely may act as an inhibitor to participation and lead to trip cancellations (Tervo, 2008). The atmospheric effects of weather can be modified by behavioural responses such as avoiding unfavourable weather, changing activities to suit weather conditions, the use of structural or mechanical aids such as umbrellas, and adjusting the thermal insulation of the body through changing clothing (de Freitas, 2001). Weather conditions can also impact on tourists through transportation delays, cancellations and accidents (Koetse \& Rietveld, 2009). Tourists' safety has been linked to extreme weather events such as heat waves (Scott \& Lemieux, 2010) and tropical storms (Becken et al., 2011). Climate change will exacerbate these risks in the future (Nyaupane \& Chhetri, 2009). 
Weather impacts may be moderated by a variety of factors including those associated with the destination itself and the type of holiday the tourist is on (Denstadli et al., 2011; Limb \& Spellman, 2001). Urban breaks or cultural tours, for example, are not as dependent on weather conditions as are holidays reliant on natural resources, or primarily involving participation in outdoor activities (Smith, 1993). However, not all tourists perceive the weather in the same way. Limb and Spellman (2001) explored the importance of tourist memories and experiences in relation to climate for domestic holidaymakers in the UK. They found that weather is embedded in people's holiday experiences and that different groups of people evaluate and remember weather in different ways. Also, 'good' and 'bad' weather may vary with circumstances and with individual's preferences, rather than being absolute concepts.

Weather also influences how enjoyable an experience is and therefore tourists' satisfaction is likely to be at least partly weather dependent. Poor weather as an important source of dissatisfaction has been identified in studies in Scotland (Smith, 1993) and Australia (Coghlan \& Prideaux, 2009). The focus in many tourist satisfaction studies, however, has been on the provision of tourism and hospitality services, taking little account of the weather encountered by tourists. Surveys measuring tourists' satisfaction often demonstrate bias towards positive ratings for destination attributes (Oh, 2001; Ryan \& Huyton, 2002). Alegre and Garau (2010), however, suggest that this focus on positive attributes of a destination in satisfaction measurement scales misses the negative features that may become determining factors of overall satisfaction. They also challenge the one-dimensional construct (i.e. that one single factor can, if positive, generate satisfaction, or if negative, generate dissatisfaction) used in many studies. Instead they argue that, while the presence of certain factors might generate satisfaction, their absence does not necessarily generate dissatisfaction, and vice versa.

Despite the importance of weather to tourists, empirical research on how tourists respond to the weather conditions they encounter is relatively limited, especially for studies that give a deeper insight into behavioural responses by tourists (e.g. Dawson et al., 2011; Gössling et al., 2012). Some studies developed regression models to relate weather and participation in tourist activities (e.g. Shi et al., 2009; Scott \& Jones, 2007). Thus, in this paper we examine the impact of the weather on a sample of international tourists visiting New Zealand during the 2009-10 summer season. A tourist survey collected data about weather-related changes made to tourists' travel routes, the timing of their travel and activity participation whilst in 
New Zealand. This information formed the basis of a segmentation analysis, which categorized tourists into three groups: those with 'no travel changes', 'some travel changes' and 'substantial changes' to their travel. Further analysis examined these segments in respect of demographic and trip characteristics, pre-trip weather expectations, during-trip engagement with weather information and the impact of the weather on their trip satisfaction.

With a focus on tourists, and on the impacts of the weather on their travel, the paper highlights an important piece of the tourism, weather and climate puzzle, and offers a more complete view of the factors that might influence adaptive capacity of tourists in New Zealand. This addresses the finding of Gössling et al. (2012) that "little is actually known about the complexity of demand responses" when it comes to responding to climate variability or change. It has long been noted that for climate change strategies to be effective, it is useful to understand the present sensitivities to climate and weather (e.g. Smit \& Wandel, 2006). This is highly relevant as many of the projected climate changes for New Zealand are an intensification of current weather events, for example the West Coast of New Zealand is getting wetter and the eastern parts are getting drier (National Institute of Water \& Atmosphere (NIWA), 2008a).

\section{Tourists and the weather in New Zealand}

Tourism in New Zealand is a highly weather and climate dependent industry with many of the popular attractions enjoyed by tourists based outdoors. Further, visitation is seasonal: the peak summer months of December 2010 to February 2011 attracted 35\% of all international tourist arrivals in the year ended March 2011 (Ministry of Economic Development, 2012). It is common practice in New Zealand for international tourists to take touring holidays during which they visit multiple regions and sub-destinations within the country (Becken, 2005) and participate in highly weather-sensitive activities. Even in benign conditions, the New Zealand climate exposes international tourists to a wide variety of weather conditions (Wilson \& Becken, 2011) which result from the country's complex climatic geography.

While relatively narrow - the coast is never more than 120 kilometres away - New Zealand stretches almost 1,600 kilometres from north to south (spanning $13^{\circ}$ of latitude), and reaches elevations of almost 4,000 metres in the Southern Alps. The temperature ranges from subtropical in the far north, to cool temperate climates in the far south. The prevailing westerly winds provide for very wet conditions on the west coast of the South Island and a 
dry climate in the east (NIWA, 2008a). In addition to the regional climatic diversity created by these conditions, the speed and frequency of weather changes are of note (Tourism New Zealand, 1999-2010). It is often said that in New Zealand you can experience 'four seasons in one day'. To date, however, limited empirical attention has been paid to the interaction of tourism, climate and weather in New Zealand. An earlier study explored the role of rainfall on the (wet) West Coast in relation to visitation at the Franz Josef visitor centre. However, other factors, including annual seasonality, dominated the model with rainfall accounting only for a very small proportion of variation (Meyer \& Dewar, 1999).

More recently, Scott et al. (2008b) investigated preferred climates for tourism, which included New Zealand as one of three case studies. The research attempted to define optimal climatic conditions by examining four climatic parameters (temperature, precipitation, sunshine and wind) in three major tourism environments (beach-coastal, urban and mountains). The study was notable for incorporating multiple weather parameters, destination types and nationality preferences. Other research includes an analysis of media articles on tourists/tourism and the weather which identified a range of weather impacts on tourists (Wilson \& Becken, 2011) and an exploration of tourists' awareness of, and preparedness for, extreme weather events (Jeuring, 2011). A number of other tourism and recreation studies, while not specifically addressing climate or weather, have also noted 'climatic' impacts on tourists. In a study of self-drive tourists' trip planning and decision-making, Becken and Wilson (2006) found that tourists' travel plans commonly changed because of the weather. Ritchie (1998) identified weather as an important factor for cycling while Bentley and Page (2008) highlighted the role played by weather in adventure tourism accidents.

\section{Method}

Against the background of limited research on how tourists respond to weather conditions, we took an exploratory approach to investigate the impacts of the weather on tourists' travel. A survey of international tourists and their weather expectations and experiences in New Zealand was administered to collect a large number of data, thus generating a wide-ranging overview of the key issues. In addition, the survey format allowed for the inclusion of openended questions (further supporting the research's exploratory nature) to collect qualitative data. Weather details were captured through the open-ended responses to several of the weather-experience questions. In addition, survey period served as a proxy to represent the type of weather tourists may have encountered. The validity of this proxy was supported by 
the 2009-10 seasonal climate summary which reported that it was a "... topsy-turvy summer. It started out extremely cold, with record cold temperatures in early December, but finished hot, with heat waves and above average temperatures in February" (NIWA, 2008b). Thus, it was hypothesised that those surveyed in early summer would have been more disrupted by the weather.

\section{Data collection}

Data were collected from international tourists at the end of their New Zealand holidays. The 15 minute-survey was in English and designed for self-completion by respondents. Two survey periods were selected to represent times when there are usually variations in the weather conditions: an 'early summer' (mid-December 2009 - early January 2010) period with more unsettled weather; and a 'late summer' (February 2010) period, reflecting more settled weather. The survey was carried out in central Christchurch and at the KEA Campers Christchurch depot. In Christchurch, several sites popular with tourists were selected and any persons who appeared to be international tourists were approached and asked to participate in the survey. To be eligible, tourists had to be from overseas, aged over 18 years, at the end of their New Zealand holiday, and understand English to a sufficient standard. Only one person in each travel group completed the survey. At the KEA Campers Depot, the survey was distributed to international tourists returning campervans, and KEA staff were asked to explain that tourists' participation was voluntary and the research was in no way connected to KEA Campers.

Altogether, 436 surveys were completed. More than half of the surveys $(\mathrm{N}=251)$ were completed in central Christchurch and 185 surveys were completed at the KEA depot. Because of the differences in the sampling frameworks comparative response rates are difficult to calculate. Of the eligible tourists approached in central Christchurch there were 26 and 23 refusals during the first and second survey periods, respectively. The completion rate at the KEA depot was influenced by how busy the staff were and by how much time the tourists had to spare. During the first survey period, when 93 surveys were completed, there were 260 campervan returns; during the second survey period, when 92 surveys were completed, there were 219 campervan returns. Some of these returns may have been New Zealanders, who were not eligible to complete the surveys. A number of survey forms were returned at the KEA depot with an insufficient number of questions answered for inclusion in the final data set. The response rates across both survey periods were 84 percent in Christchurch and 39 percent at the KEA depot. 


\section{Analysis}

Three questions in the larger survey (Becken et al., 2010) were of particular interest, namely respondents' weather-related changes to a) the time they spent in a place; b) the route they travelled; or, c) their activities. For each of these questions, tourists could respond 'no change', 'occasionally', and 'frequently', and they were asked to provide examples if they had made any changes. It is acknowledged that tourists' assessment of occasional versus frequent is subjective; however, the segmentation (see below) was based on combining these two answers into 'any change'. Only those 309 respondents who answered all three 'change' questions have been included in the analysis for this paper. The three travel components for which changes were examined are likely inter-related. This potential collinearity would need to be considered in future statistical models, for example regression analysis.

The survey data were analysed using SPSS Version 17.0 for the purpose of descriptive statistical analyses, and nonparametric tests (Chi Square). Open-ended questions were manually coded and analysed qualitatively. The 309 respondents were coded into three groups: those who made 'substantial travel changes', i.e. they reported having changed all three dimensions (i.e. timing, route and activity) because of weather conditions; those who made 'some changes', i.e. they made changes in only one or two of these dimensions; and those who made 'no changes'. The segmentation into three travel change groups was the basis of further statistical analysis including: key data describing respondents' demographics (age, country of residence) and trip characteristics (transport used, length of stay); expectations of weather pre-trip and engagement with weather information during-trip; and weather impact on satisfaction. Data were aggregated to a level that allowed Chi-square tests (i.e. cell counts of 5 or more) to avoid Type II error where there are differences between groups but because of small sample sizes they remain undetected.

\section{Limitations}

A major limitation is that the survey did not collect specific weather data. The reason for this was that because the survey was an exit survey and tourists were asked about their experiences of their total trip, it was not practical to collect detailed daily weather data. For the case of New Zealand, this would be particularly difficult considering that the average tourists stays for about 21 days and would have been likely to have experienced changeable weather throughout their trip. Thus, it would be challenging to ask tourists to summarise the weather they experienced. Instead, the impact of weather was captured more indirectly by asking how tourists changed components of their travel and whether weather affected their 
satisfaction. These are subjective measures and reflect the tourists' perception of how weather affected their trip.

Another limitation is that the survey did not count how many times tourists made changes, nor did it explore the nature of changes in any detail. Further, tourists who reported no changes because of the weather could have been fortunate in that they encountered favourable weather or they chose not to make any changes despite the weather. The framework developed at the end of this paper accounts for this possibility and proposes further avenues for research. Finally, due to the survey approach, the sample is biased towards independent tourists from European countries. For example, the most common countries of origin in this sample are Germany (20\%) and the UK (16\%), which compares to a proportion of $2 \%$ and $8 \%$ in the whole tourist population. The proportion of tourists who travel in a car, van or campervan is $74 \%$ in this sample compared with $73 \%$ in the tourist population. Tour group visitors, however, are slightly underrepresented (15\% compared with 24\%) (Ministry of Economic Development, 2012). For the development of the framework and the underlying principles of adaptive capacity, this bias is not problematic.

\section{Results}

The results are presented in three parts: 1) Changes due to the weather; 2) Travel change group and key demographic and trip characteristics; 3) Travel change group and weather experiences, information engagement and satisfaction.

\section{Changes due to weather}

Respondents reported a number of changes to their trip in response to the weather with most changes made to activities, followed by length of stay (timing) in a particular destination; travel route was the least likely to change as a result of the weather (Table 1). For all three types of change, however, most changes were made only occasionally, suggesting that the weather did not have a significant impact on tourists' travel and activities, either because it was generally favourable or because tourists made no change despite detrimental weather.

\section{TABLE 1}

The open-ended responses provided insight into what weather-related changes tourists made. The most common change reported with respect to travel timing was to either leave a place 
early because of bad weather, or stay longer because of good weather. Some respondents waited for the weather to improve or, based on the weather forecast, they cancelled plans to visit a place. Some also reported having driven past intended stops because of bad weather, or continued driving in the hope of finding better weather, both of which resulted in covering more ground than intended in one day. Many of the examples provided related to the typical weather conditions found in specific destinations, e.g. leaving the (very wet) West Coast of the South Island early because of bad weather, staying longer in (sunny) Golden Bay because of good weather and waiting at Milford Sound for the (notoriously bad) weather to improve. Milford Sound is one of the major tourist attractions in New Zealand and a priority for tourists to visit (Becken, 2005). Only a quarter of respondents changed the routes they travelled, reflecting the popularity of a number of iconic destinations and the limited variation of road routes available to connect these sites (Becken \& Wilson, 2006; Pearce, 1990). Some respondents, however, changed the order in which they visited particular destinations, or the direction in which they travelled ("there was much rain west, so went east"; "came down the West Coast first to follow the sun").

Just over half of all respondents changed activities because of the weather. The specific locations mentioned, were the primary tourist destinations of the Glaciers, Tongariro, Milford Sound, Abel Tasman, Kaikoura and Queenstown. Land-based activities were the most affected followed by water and air-based ones, which reflects the frequency of participation in these different types of activity. The wide range of weather impacts on commercial activities included: the cancellation of guided walks and because of heavy rain; the cancellation of scenic flights, sky diving, paragliding because of poor visibility and high winds; the closure of gondolas and cancellation of Whale Watch because of high winds; and the cancellation of jet boating, canyoning, sea and river kayaking because of heavy rain and high water levels. Of the activities commonly undertaken independently, walking/tramping, beach visits and swimming were the most frequently mentioned in respect of weather impacts. Some respondents reported waiting for good weather to do particular hikes ("we timed some bush walks for the weather, we also walked a lot in the rain"; "scheduled summit trip on Mt Taranaki after weather change"). A number of respondents reported doing more indoor activities when the weather was bad ("museum instead of hiking").

When examined by survey period, the number of respondents who made no changes was smaller in early summer compared with late summer for all three measures (Figure 1); however, this was only statistically significant with respect to activities $\left(X^{2}=13.767, \mathrm{df}=2\right.$, 
$\mathrm{p}=0.001$ ). For example, in early summer 56 respondents made no changes to their activities (while 92 did), compared with 94 in late summer who made no changes (and 67 did change their activities).

\section{FIGURE 1}

\section{Travel change group and key demographic and trip characteristics}

According to the segmentation described earlier, 51 tourists $(16.5 \%)$ reported making 'substantial travel changes' and 145 (46.9\%) respondents made 'some changes' to their trip; the remaining $113(36.6 \%)$ respondents reported 'no travel changes' as a result of the weather (Figure 2). A significant relationship was found between survey period and travel change group $\left(\mathrm{X}^{2}=14.548, \mathrm{df}=2, \mathrm{p}=0.001\right)$. Altogether, almost two thirds $(66.4 \%)$ of tourists making no travel changes were surveyed in late summer, compared to less than half of each of the tourists making some or substantial changes ( $44.1 \%$ and $43.1 \%$ respectively).

\section{FIGURE 2}

Further analyses were undertaken to examine whether different types of tourists (i.e. according to demographics and key trip variables) were relatively more likely to have changed their trip or not (assuming that tourists typically encounter a similar mix of weather conditions). These data included country of residence, age, number of previous visits to New Zealand, length of stay on current trip, and main mode of transport used (Table 2). While following intuitive patterns, only age produced a significant relationship as shown in Table 2 . Respondents in the age group of 41-44 years, were most likely to have made substantial changes to their trip, while both the young tourists (18 to 25 years) and the older ones (over 56) were least inclined. No clear pattern of travel changes because of the weather by country of residence was found. First time visitors were slightly more likely to have made substantial travel changes, i.e. $18.9 \%$ of all first timers were of the 'substantial travel change' group, compared to $13.7 \%$ of those who had made one previous visit and only $8.6 \%$ of those who had made more than one previous visit. Tourists who had visited more than once previously were much more likely to report no changes to their trip (48.6\% compared to $35.8 \%$ of first time visitors and $32.9 \%$ of those who made one previous visit). This suggests that, as the 
number of previous visits a tourist has made to New Zealand increases, so too does their understanding of the weather's impact on their travel plans.

The degree to which tourists made changes in response to weather conditions was moderated by transport mode and length of stay although, again, no statistically significant relationships were found. Tourists travelling by campervan were most likely to have made substantial changes, followed by those using public transport or travelling independently. As might be expected, those on tours were more likely to be of the 'no travel change' group (50.0\%) and less likely to have made substantial changes (4.3\%). Tourists on short stays (under 2 weeks) were more likely to report no changes compared with those on longer stays (48.1\% compared to only $29 \%$ ). This is possibly a consequence of shorter stay tourists having more components of their trip pre-booked, thus reducing their ability to change their trip. Also, tourists' exposure to a greater variability of weather conditions increases with length of stay.

\section{TABLE 2}

\section{Travel change group and weather expectations, information seeking and satisfaction}

Respondents were asked what they thought the weather would be like before they got to New Zealand and if the weather they experienced was different to what they had expected. Most respondents $(60.8 \%)$ found the weather in New Zealand different to what they expected. A statistically significant relationship was found whereby, encountering different weather to expected, increased the likelihood of making travel changes. Of those who did find the weather different to expected, almost half $(47.9 \%)$ had made some travel changes and a fifth (20.2\%) made substantial changes because of the weather (Table 3). This relationship was even more pronounced in early summer. The 188 respondents who found the weather different to expected were also asked in what way it differed. These responses were compared with the open-ended responses recorded for 'expected weather pre-trip' and coded into three categories: better than expected; worse than expected; and unexpected/different (e.g. "varied") (13 respondents did not provide further comment). Tourists who experienced worse than expected weather were much more likely to make changes to their travel (82\%) compared with those who perceived the weather to be better or different.

\section{TABLE 3}


Altogether, 25.3 percent reported seeking weather information regularly, 165 (53.6\%) occasionally and 21.1 percent not at all. The results in Table 3 show that information use increases with the extent to which tourists changed their travel, i.e. regular users of weather information were more likely to be in the 'substantial travel change' group (28.2\%), compared with those who did not access weather information. The final analysis examined whether the extent to which tourists made changes to their trip related to the impact that weather had on their satisfaction (Figure 3). Overall, a large number of tourists reported a positive weather impact on their holiday satisfaction (43.5\%), compared to only a relatively small proportion $(7.5 \%)$ for whom the weather impacted negatively. Almost half $(49.0 \%)$ were ambivalent, i.e. they reported that the weather had little or no influence. As the level of changes made increased, the likelihood of reporting a positive weather experience decreased, indicating that making changes is an undesired measure. The proportion of tourists reporting positive effects was much smaller in early summer, a reflection of more disruptive weather conditions and higher incidence of weather-related changes in early summer. Accordingly, the tourists surveyed in early summer were more likely to report that the weather had little or no influence, or even a negative influence on their satisfaction (Figure 3).

\section{FIGURE 3}

\section{Discussion}

Climate and weather are important drivers for international tourism, and the decision by tourists to travel to New Zealand in summer (i.e. December to February) indicates that the weather plays some part in the overall timing of New Zealand holidays, particularly for tourists from the northern hemisphere who may wish to escape their own winter season. Once in New Zealand, the combination of multi-destination travel, with a focus on outdoor activities, and the variability of the weather, both spatially and temporally, does appear to have some impact on tourists' itineraries and activity patterns.

This research found that the majority of respondents (63\%) made some changes to their trip as they travel because of the weather. Tourists changed the length of time they stay in a destination and, to a lesser extent, the routes they take, but the weather had most impact on their activities. Tourists were segmented into three groups based on whether they made no weather-related changes, some or substantial travel changes. Those who made no changes were more likely to be older, to have visited a number of times previously, travel by tour or 
car and stay the shortest length of time. This suggests a combination of adequate previous knowledge to make realistic plans, less interest in weather-impacted activities, less scope to make changes even if they wanted to because of time and other constraints. 'No travel change' tourists were the least likely to find the weather different to expected or to use weather information whilst travelling. This group was also more prominent in late summer, the more settled weather period, and were the most likely to report a positive weather influence on satisfaction.

At the other extreme, tourists who made changes to all three dimensions of their travel ('substantial travel change', the smallest of the three groups), were more likely to be in the middle age groups, on their first visit, travel by campervan and stay either short (i.e. less than 2 weeks) or long (over a month). This group had the highest percentage of tourists who found the weather different to expected and the highest percentage of regular users of weather information whilst travelling. This suggests less prior knowledge of New Zealand weather, alongside greater flexibility to change plans. These tourists were also the most likely to report that the weather had a negative influence on satisfaction, suggesting that having to change one's trip because of the weather is not desirable. The early less settled summer period saw a slightly higher percentage of tourists with substantial trip changes. Finally, tourists who made 'some changes' (the largest group) were more likely to be young, to be on their first visit or to have visited once, travel by campervan and stay for medium or long time. This group had the highest percentages of tourists who found the weather different to expected, collected weather information occasionally and reported that the weather had little or no influence on satisfaction. These tourists' responses to the weather were moderate and reflected general ambivalence to the weather (as in a small-scale study by Limb \& Spellman, 2001).

This study has highlighted some of the difficulties of understanding weather impacts on tourists. Because of their diverse itineraries and activity patterns, the (highly variable) weather tourists encounter in New Zealand cannot simply be described in terms of a single destination and activity type (e.g. Moreno et al., 2008). This complexity raises questions about the assessment of 'optimal climatic conditions' through indices based on coarse monthly scale data for destinations such as New Zealand. Rather than trying to assess ideal conditions the better approach might be to understand tourists' preferences for specific locations and activities (Rutty \& Scott, 2010) and contrast these with the realities occurring at the destination. To study the detailed impact of weather on travel decisions it would be necessary to collect (half) daily data from individual tourists on what they had planned, what 
the weather was, and what they decided to do. The trade-off would be that such a diary approach would only be able to cover a limited number of days of a tourist's trip, if reasonable response rates are expected.

In this research, a broader approach examined tourists' experiences with the weather in New Zealand across their whole trip. Thus, no detailed weather data were collected and the behavioural responses by tourists could not been controlled for by specific conditions. To introduce some element of weather context, the use of survey periods served as a proxy for the weather tourists were likely to encounter. Thus, surveying tourists at the end of their holidays ensured that, within the sample, tourists had experienced either 'early summer' or 'late summer' conditions. The difference in weather conditions between these was validated by the NIWA (2008b) seasonal climate summary, and by the research data themselves, which showed that early summer tourists made more weather-related changes to their trips. The examination of tourists' weather expectations, and the finding that many more tourists experienced 'worse than expected' weather in early summer, also supports our early and late summer weather-proxies.

While this study was exploratory in nature and the sample of tourists is biased towards European free independent travellers a conceptual framework for tourists' responses to weather is proposed (Figure 4). This framework could be used as a starting point for a detailed quantitative survey to disentangle the different antecedents that lead to the particular (observed) behaviour of changing one's trip or not. The framework first assumes that international tourists arrive at a destination with specific expectations, levels of preparation (including in anticipation of the destination's climate), travel plans and budgets, and decision making heuristics, including hedonic behaviour (Hyde, 1999; Woodside \& King, 2001). Decision-making relates to demographics, previous travel experience, and trip characteristics, amongst others. The weather is treated as a situational factor that influences en route decision making, sometimes in a planned way (e.g. in response to a weather forecast) and other times more impulsively (Becken \& Wilson, 2006). Hence, the weather tourists encounter facilitates what tourists had planned to do, and it is the pivotal base from which tourists are likely to consider making changes or not. This research indicates that if the weather is suitable for what tourists want to do, no changes occur because of the weather. If changes are made it is typically in response to unfavourable weather, rather than maximising 'utility' by exploiting favourable conditions. This asymmetry of weather impacts on behaviour is worthy of greater investigation in future research. 
If tourists encounter weather that may require a change of their route, timing or activities, changes may or may not be possible. Some trip characteristics operate as constraints and others facilitate change; a short length of stay, for example, restricts capacity to make changes. Certain types of tourists have a greater built-in flexibility than others, for example campervan tourists who reported greater levels of change compared with group tourists. Finally, not all tourists who are able to make changes in response to detrimental weather will chose to do so. This could relate to tourist personalities or different levels of tolerance towards weather conditions, and further research on this would be useful. Tourists who chose to make changes then fall into the 'some travel changes' or 'substantial travel changes' group. The availability and use of climate and weather information before and during the trip constitutes an important element of the framework. Tourists who use climate information before their trip are better prepared, have realistic expectations and are less likely to change their trip. Using information during the trip, in this research, appeared to be more relevant for those tourists who had to or decided to make changes to their trip because of the weather. This is an important finding, as the use of information may not only lead to better choices, but also contribute to protecting tourists from severe weather events and (Jeuring, 2011). Given that more than half of the respondents in this research found the weather different to expected, the role of weather information deserves greater attention.

The relationship between changing one's trip and satisfaction is of great interest. Tourists who reported more changes than others were more likely to report that the weather had a negative impact on satisfaction. To what extent this drives overall satisfaction has not been explored in this research, but should be considered more specifically in future market research. Higher levels of changes made, i.e. moving through the grey shaded boxes in Figure 4, may reduce satisfaction, perhaps because of the effort changes involve. The fact that more people reported negative impacts in the early summer season, compared with the February survey period, raises questions about New Zealand's attempt to extend the shoulder seasons into periods that are possibly offering less favourable weather conditions. Implications on tourist experience and resulting word-of-mouth messaging should be assessed (Becken et al., 2010).

\section{FIGURE 4}

The findings from this weather-related research provide a first insight into tourists' responses to climate variability and future climate change, thus further exploring Scott et al.'s (2008) 
and Gössling et al.'s (2012) proposition that tourists have a great adaptive capacity. Climate change adaptation starts at home. Tourists who prepare for their trip and understand the climate of their destination are better prepared than those who travel with little knowledge of potential weather conditions they might encounter. Such adaptation includes a conscious decision to travel during times that provide most likely suitable weather (e.g. the late summer in New Zealand). Further, some forms of tourism might be more amenable to 'adapting' to changing conditions during travel than others. Flexible arrangements, such as campervan holidays, are probably more adaptable than pre-booked bus tours. At the same time, it is important to note that, whilst more adaptable, campervan tourists are more exposed to the climate. The individual tourist's mind-set is also likely to influence adaptive capacity, but research on this aspect has not been undertaken yet. Finally, high users of weather information are also likely to have higher 'adaptive capacity' than tourists who do not engage with local weather information and forecasts.

\section{Conclusion}

A tourist survey, undertaken to explore tourist and weather interactions, collected data about weather-related changes made to tourists' travel routes, the timing of their travel and activity participation whilst in New Zealand. This information formed the basis of a segmentation, which categorized tourists into those who made no changes to their trip, and those tourists who made some or substantial travel changes. The research found that a large number of tourists changed their trip because of the weather, typically in response to unfavourable conditions, lending weight to the assumptions that tourists have a high adaptive capacity. Notwithstanding, about a third of visitors made no changes to their trip, which can be explained by them either 'being lucky' with the weather, facing constraints (e.g. being on a fixed tour), or being unwilling to make changes. Whether tourists' potential reluctance to make changes relates to psychological variables or decision-making patterns remains an interesting question. Importantly, tourists who made no changes appeared more satisfied with the weather compared with those who did change their trip in response to weather. This research indicates that tourists prefer not to make changes to their trip to accommodate weather conditions. Thus, adapting to weather is a matter of 'damage control' rather than optimising utility. Thus, the link between adaptation to weather and overall satisfaction is potentially important for destinations that are exposed to highly variable weather. This research highlights the complexity of understanding climate variability and change in relation 
to tourist behaviour. Finally, the comparison between tourist behaviour and weatherinfluenced satisfaction between the early summer and the more settled late summer season with a reported greater need to make changes to travel plans in early summer, poses severe challenges to those who wish to extend tourism beyond the peak season into the less popular shoulder seasons. 


\section{References}

Alegre, J., \& Garau, J. (2010). Tourist satisfaction and dissatisfaction. Annals of Tourism Research, 37(1), 52-73.

Becken, S. (2005). The role of tourist icons for sustainable tourism. Journal of Vacation Marketing, 11(1), 17-26.

Becken, S., \& Wilson, J. (2006). Trip planning and decision making of self-drive tourists - a quasi-experimental approach. Journal of Travel and Tourism Marketing, 20(3/4), 4762.

Becken, S., Wilson, J. \& Hughey, K. (2011). Planning for Climate, Weather and Other Natural Disasters - Tourism in Northland. LEaP Research Paper 1. Available at www.lincoln.ac.nz/leap

Becken, S., Wilson, J. \& Reisinger, A. (2010). Weather, climate and tourism: a New Zealand perspective. Lincoln University, New Zealand: LEaP. (Land Environment and People Research Report No. 20). Available at www.linclon.ac.nz/leap

Bentley, T. A., \& Page, S. J. (2008). A decade of injury monitoring in the New Zealand adventure tourism sector. Tourism Management, 29(5), 857-869.

Coghlan, A. \& Prideaux, B. (2009). Welcome to the Wet Tropics: the importance of weather in reef tourism resilience. Current Issues in Tourism, 12(2), 89-104.

de Freitas, C.R. (2001). Theory, concepts and methods in tourism climate research. In Proceedings of the First International Workshop on Climate, Tourism and Recreation (pp. 3-20). A. Matzarakis and C. R. de Freitas (Eds.). Report of a Workshop held at Porto Carras, Neos Marmaras, Halkidiki, Greece, 5 -10 October 2001. International Society of Biometeorology. Downloaded from http://www.urbanclimate.net/cctr/ws/papers/full_report.pdf

Dawson, J., Havitz, M., \& Scott, D. (2011). The influence of ego involvement on climateinduced substitution and place loyalty among alpine skiers. Journal of Travel and Tourism Marketing, 28, 388-404.

Denstadli, J.M. Jacobsen, J.S. \& Lohmann, M. (2011). Tourist perceptions of summer weather in Scandinavia. Annals of Tourism Research, 38, 3, 920-940.

Giles A.R., Perry A.H. (1998). The use of a temporal analogue to investigate the possible impact of projected global warming on the UK tourist industry. Tourism Management, 19(1), 75-80.

Gómez Martín, Ma. (2005). Weather, climate and tourism: a geographical perspective. Annals of Tourism Research, 32(3), 571-591.

Gössling, S., Scott, D., Hall, C.M., Ceron, J.P. \& Dubois, G. (2012). Consumer behaviour and demand response of tourists to climate change. Annals of Tourism Research, available online doi:10.1016/j.annals.2011.11.002

Hadwen, W., Arthington, A., Boon, P., Taylor, B. \& Fellows, C. (2011). Do climatic or institutional factors drive seasonal patterns of tourism visitation to Protected Areas across diverse climate zones in Eastern Australia? Tourism Geograpies, Online.

Hamilton, J.M. \& Lau, M. (2005). The role of climate information in tourist destination choice decision-making. In Tourism and Global Environmental Change (pp. 229-250). S. Gössling, and C.M. Hall (Eds.). London: Routledge.

Hein, L., Metzger, M. \& Moreno, A. (2009). Potential impacts of climate change on tourism; a case study for Spain. Current Opinion in Environmental Sustainability, 1, 170-178.

Hu, Y. \& Ritchie, J. (1993). Measuring destination attractiveness: a contextual approach. Journal of Travel Research, 32(2), 25-34.

Hyde, K. (1999). A hedonic perspective on independent vacation planning, decision-making and behavior. In Consumer psychology of tourism, hospitality and leisure, A. 
Woodside, G. Crouch, J. Mazanec, M. Oppermann and M. Sakai, eds., pp. 177-191. Wallingford: CABI Publishing.

Jeuring, J. (2011). Intentions to seek severe weather information among travelers in New Zealand. Master's Thesis - Tourism, Leisure and Environment, Wageningen University and Research Centre, The Netherlands.

Koetse, M.J. \& Rietveld, R. (2009). The impact of climate change and weather on transport: An overview of research findings. Transportation Research Part D.

Limb, M. \& Spellman, G. (2001). Evaluating domestic tourists' attitudes to British weather: A qualitative approach. In Proceedings of the First International Workshop on Climate, Tourism and Recreation. A. Matzarakis and C. R. de Freitas (Eds.), Report of a Workshop held at Halkidiki, Greece, 5 -10 October. Available at (20/01/2011) http://www.urbanclimate.net/cctr/ws/papers/full_report.pdf

Maddison, D. (2001). In search of warmer climates? The impact of climate change on flows of British tourists. Climatic Change, 49, 193-2208.

Meyer, D. \& Dewar, K. (1999). A new tool for investigating the effect of weather on visitor numbers. Tourism Analysis, 4 (3/4), 145-155.

Mieczkowski, Z. (1985). "The Tourism Climatic Index: A Method of Evaluating World Climates for Tourism." Canadian Geographer, 29 (3): 220-233.

Ministry of Economic Development (2012). Core Tourism Data Set. Available at (29/07/12) http://www.infotools.com/MEDviewer/?PageLocation=MED/CubePages/MED_IVS_T ravelPatterns

Moreno, A., Amelung, B. \& Santamarta, L. (2008). Linking Beach Recreation To Weather Conditions. A Case Study In Zandvoort, Netherlands. Tourism in Marine Environments, 5 (2/3),111-120.

Morgan, R., Gatell, E. Junyent, R. Micallef, A., Özhan E., \& Williams, A.T. (2000). An improved user-based beach climate index. Journal of Coastal Conservation, 6(1), 4150 .

National Institute of Weather and Atmospheric Science (NIWA) (2008a). Overview of New Zealand climate. Available at http://www.niwa.co.nz/education-andtraining/schools/resources/climate/overview

National Institute of Weather and Atmospheric Science (NIWA) (2008b). Summer 2009-10. Available at (20/01/2012) http://www.niwa.co.nz/ourscience/climate/publications/all/cs/seasonal/summer-2009-10

Nyaupane, G. \& Chhetri, N. (2009). Vulnerability to Climate Change of Nature-Based Tourism in the Nepalese Himalayas. Tourism Geographies, 11(1), 95-119.

Oh, C.-O. H. (2001). Revisiting importance-performance analysis. Tourism Management, 22(6), 617-627.

Pearce, D. (1990). Tourism, the regions and restructuring in New Zealand. The Journal of Tourism Studies 1(2): 33-42.

Pike, S. (2002). Destination image analysis - a review of 142 papers from 1973 to 2000. Tourism Management, 23(5), 541-549.

Ritchie, B. (1998). Bicycle tourism in the South Island of New Zealand: planning and management issues. Tourism Management, 19(6), 567-582.

Rossello-Nadal, J., Riera-Font, A. \& Cardenas, V. (2011). The impact of weather variability on British outbound flows. Climatic Change, 105, 281-292.

Rutty, M. \& Scott, D. (2010). Will the Mediterranean Become "Too Hot" for Tourism? A Reassessment. Tourism and Hospitality Planning \& Development, 7(3), 267-281.

Ryan, C., \& Huyton, J. (2002). Tourists and aboriginal people. Annals of Tourism Research, 29(3), 631-647. 
Scott, D. \& Jones, B. (2007). A regional comparison of the implications of climate change of the golf industry in Canada. The Canadian Geographer, 51(2), 219-232.

Scott, D. \& Lemieux, C. (2010). Weather and Climate Information for Tourism. Procedia Environmental Sciences, 1, 146-183.

Scott, D., Jones, B. \& Konopek, J. (2008a). Exploring the impact of climate-induced environmental changes on future visitation to Canada's Rocky Mountain National Parks. Tourism Review International, 12, 43-56.

Scott, D., Gössling, S., \& de Freitas, C. R. (2008b). Preferred climates for tourism: case studies from Canada, New Zealand and Sweden. Climate Research, 38, 61-73.

Shih, C., Nicholls, S. \& D. Holecek (2009). Impact of Weather on Downhill Ski Lift Ticket Sales. Journal of Travel Research, 47(3): 359 - 372.

Smit, B. \& Wandel, J. (2006). Adaptation, adaptive capacity and vulnerability. Global Environmental Change-Human and Policy Dimensions, 16, 282-292.

Smith, K. (1993). The influence of weather and climate on recreation and tourism. Weather, $48,398-404$.

Tervo, K. (2008). The operational and regional vulnerability of winter tourism to climate variability and change: the case of the Finnish nature-based tourism entrepreneurs. Scandinavian Journal of Hospitality and Tourism, 8(4), 317-332.

Tourism New Zealand (1999-2010). Climate and weather. Available at http://www.newzealand.com/travel/about-nz/nature/nature-climate-and-weather.cfm

Wilson, J. \& Becken, S. (2011). Perceived Deficiencies in the Provision of Climate and Weather Information for Tourism: A New Zealand Media Analysis. New Zealand Geographer, 67(3), 148-160.

Woodside, A.G. \& King, R.I. (2001).An updated model of travel and tourism purchaseconsumption systems. Journal of Travel and Tourism Marketing, 10 (1), 3-26.

Yu, G., Schwartz, Z. \& Walsh, J.E. (2009). A weather-resolving index for assessing the impact of climate change on tourism related climate resources. Climatic Change, 95 (34), 551-573.

Table 1. Changes to trip timing, route and activities as a result of the weather $(\mathrm{N}=309)$

\begin{tabular}{lcccccc}
\hline & \multicolumn{2}{c}{ No change } & $\begin{array}{c}\text { Occasionally/To some } \\
\text { extent }\end{array}$ & \multicolumn{2}{c}{ Frequently/ Often } \\
\hline & Number & $\%$ & Number & $\%$ & Number & $\%$ \\
Timing & 187 & 61 & 100 & 32 & 22 & 7 \\
Route & 228 & 74 & 71 & 23 & 10 & 3 \\
Activity & 150 & 49 & 146 & 47 & 13 & 4 \\
\hline
\end{tabular}


Table 2. Key data describing research sample by 'travel change' group ( $N=309)$

\begin{tabular}{|c|c|c|c|c|c|}
\hline \multicolumn{2}{|c|}{ Sample characteristics } & \multirow{2}{*}{$\begin{array}{l}\text { Number } \\
(\%)\end{array}$} & \multirow{2}{*}{$\begin{array}{c}\text { No changes } \\
\%\end{array}$} & \multirow{2}{*}{$\begin{array}{r}\begin{array}{c}\text { Some } \\
\text { changes } \%\end{array} \\
49.2\end{array}$} & \multirow{2}{*}{$\begin{array}{r}\text { Substantial } \\
\text { changes \% }\end{array}$} \\
\hline Country of & Germany & & & & \\
\hline \multirow[t]{5}{*}{ residence } & UK & $49(15.9)$ & 44.9 & 36.7 & 18.4 \\
\hline & $\begin{array}{l}\text { Other Europe (inc. Netherlands } \\
\text { and Switzerland) }\end{array}$ & $101(32.7)$ & 35.6 & 51.5 & 12.9 \\
\hline & USA/Canada & $37(12.0)$ & 32.4 & 51.4 & 16.2 \\
\hline & Australia & $31(10.0)$ & 48.4 & 32.3 & 19.4 \\
\hline & Asia and Other & $28(9.1)$ & 28.6 & 53.6 & 17.9 \\
\hline \multirow{4}{*}{$\begin{array}{l}\text { Age* } \\
(\mathrm{X} 2=13.091, \\
\mathrm{df}=6, \mathrm{p}= \\
0.031)\end{array}$} & $18-25 \mathrm{yrs}$ & $60(19.4)$ & 26.7 & 61.7 & 11.7 \\
\hline & $26-40 \mathrm{yrs}$ & $126(40.8)$ & 37.3 & 46.0 & 16.7 \\
\hline & $41-55$ yrs & $72(23.3)$ & 31.9 & 44.4 & 23.6 \\
\hline & Over 56 yrs & $51(16.5)$ & 52.9 & 35.3 & 11.8 \\
\hline \multirow{3}{*}{$\begin{array}{l}\text { Number of } \\
\text { previous } \\
\text { visits }\end{array}$} & No previous & $201(65.0)$ & 35.8 & 45.3 & 18.9 \\
\hline & One previous & $73(23.6)$ & 32.9 & 53.4 & 13.7 \\
\hline & Two or more previous ${ }^{1)}$ & $35(11.3)$ & 48.6 & 42.9 & 8.6 \\
\hline \multirow{4}{*}{$\begin{array}{l}\text { Main } \\
\text { transport } \\
\text { mode }\end{array}$} & Campervan & $153(49.5)$ & 30.1 & 49.0 & 20.9 \\
\hline & Car (rental/private) & $73(23.6)$ & 42.5 & 43.8 & 13.7 \\
\hline & Tour (bus/cruise) & $46(14.9)$ & 50.0 & 45.7 & 4.3 \\
\hline & Public transport/independent & $37(12.0)$ & 35.1 & 45.9 & 18.9 \\
\hline \multirow{3}{*}{$\begin{array}{l}\text { Length of } \\
\text { stay }\end{array}$} & Short ( $\leq 2$ weeks $)$ & $54(17.5)$ & 48.1 & 33.3 & 18.5 \\
\hline & Medium $(>2$ weeks $\leq 1$ month) & $162(52.4)$ & 37.0 & 47.5 & 15.4 \\
\hline & Long (> 1 month) & $93(30.1)$ & 29.0 & 53.8 & 17.2 \\
\hline
\end{tabular}

* Significant at the $5 \%$ level.

1) One cell has less than 5 counts, however, aggregation into two groups did not reveal any different results. 
Table 3. Chi-square results for planning, information and satisfaction variables by 'travel change' group.

\begin{tabular}{|c|c|c|c|c|c|c|}
\hline & & Number (\%) & $\begin{array}{l}\text { No changes } \\
\%\end{array}$ & $\begin{array}{c}\text { Some } \\
\text { changes } \%\end{array}$ & $\begin{array}{l}\text { Substantial } \\
\text { changes \% }\end{array}$ & $\begin{array}{c}\text { Chi- } \\
\text { square } \\
\text { p-value }\end{array}$ \\
\hline $\begin{array}{l}\text { Weather } \\
\text { different to } \\
\text { expected } \\
(\mathrm{N}=309)\end{array}$ & $\begin{array}{l}\text { Yes } \\
\text { No }\end{array}$ & $\begin{array}{l}188(60.8) \\
121(39.2)\end{array}$ & $\begin{array}{l}31.9 \\
43.8\end{array}$ & $\begin{array}{l}47.9 \\
45.5\end{array}$ & $\begin{array}{l}20.2 \\
10.7\end{array}$ & .031 \\
\hline $\begin{array}{l}\text { Nature of } \\
\text { difference } \\
(\mathrm{N}=175)\end{array}$ & $\begin{array}{l}\text { Worse } \\
\text { Better } \\
\text { Different }\end{array}$ & $\begin{array}{l}88(50.3) \\
52(29.7) \\
35(20.0)\end{array}$ & $\begin{array}{l}18.2 \\
51.9 \\
40.0\end{array}$ & $\begin{array}{l}56.8 \\
34.6 \\
42.9\end{array}$ & $\begin{array}{l}25.0 \\
13.5 \\
17.1\end{array}$ & 0.001 \\
\hline $\begin{array}{l}\text { Weather } \\
\text { information } \\
\text { whilst travelling } \\
(\mathrm{N}=308)\end{array}$ & $\begin{array}{l}\text { No } \\
\text { Occasionally } \\
\text { Regularly }\end{array}$ & $\begin{array}{r}65(21.1) \\
165(53.6) \\
78(25.3)\end{array}$ & $\begin{array}{l}58.5 \\
32.1 \\
26.9\end{array}$ & $\begin{array}{l}30.8 \\
54.5 \\
44.9\end{array}$ & $\begin{array}{l}10.8 \\
13.3 \\
28.2\end{array}$ & .000 \\
\hline $\begin{array}{l}\text { Weather } \\
\text { influence on } \\
\text { satisfaction } \\
(\mathrm{N}=308)^{1)}\end{array}$ & $\begin{array}{l}\text { Positively } \\
\text { Little or no } \\
\text { influence } \\
\text { Negatively }\end{array}$ & $\begin{array}{r}134(43.5) \\
151(49.0) \\
23(7.5)\end{array}$ & $\begin{array}{l}48.5 \\
29.8\end{array}$ & $\begin{array}{l}38.8 \\
55.0 \\
43.5\end{array}$ & $\begin{array}{l}12.7 \\
15.2 \\
47.5\end{array}$ & .000 \\
\hline
\end{tabular}

1) One cell has less than 5 counts. 


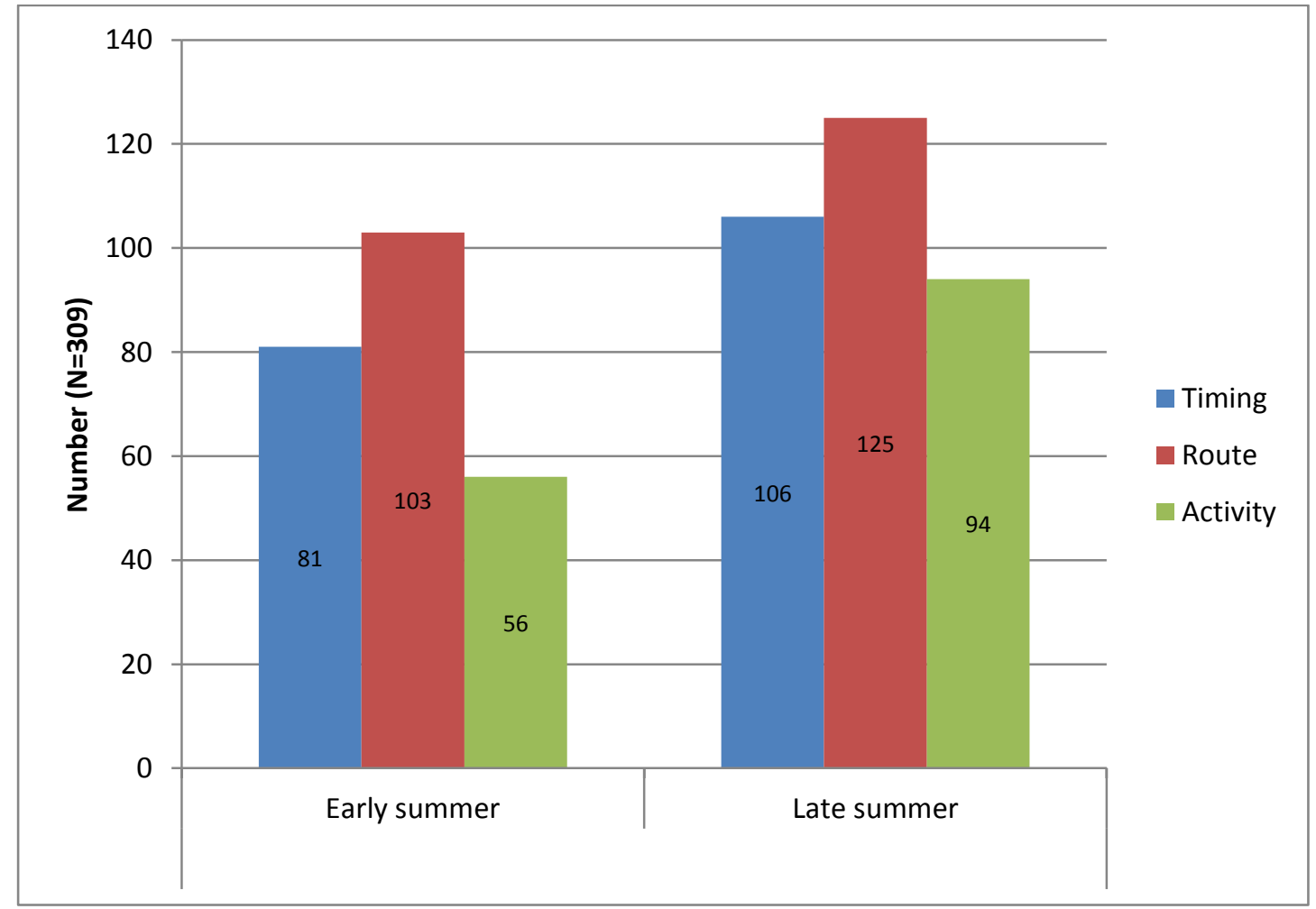

Figure 1. Number of respondents who reported no changes to timing, route and activity by survey period. 


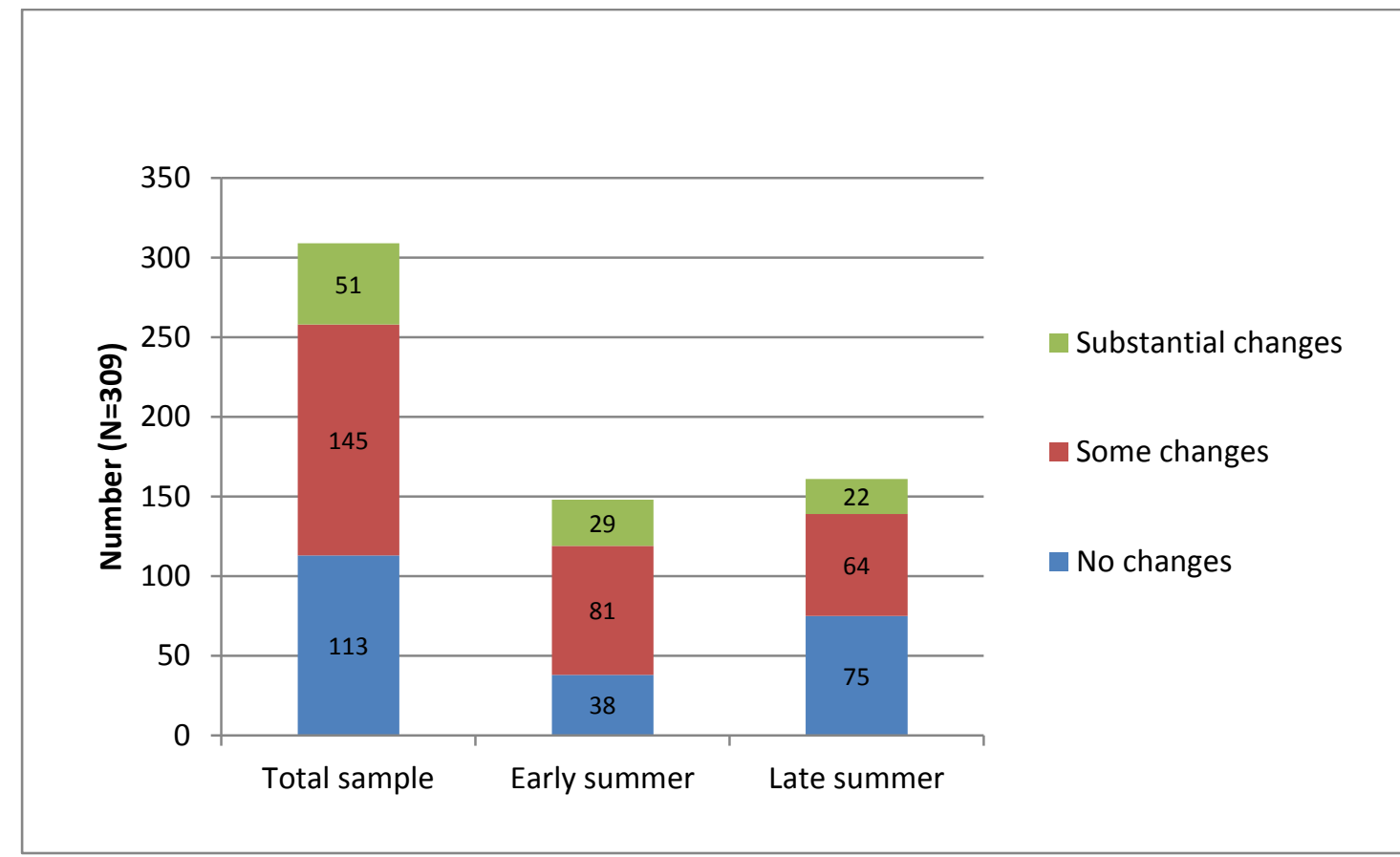

Figure 2. Prevalence of travel change groups ('no change', 'some change', 'substantial change') for total sample and by survey period. 

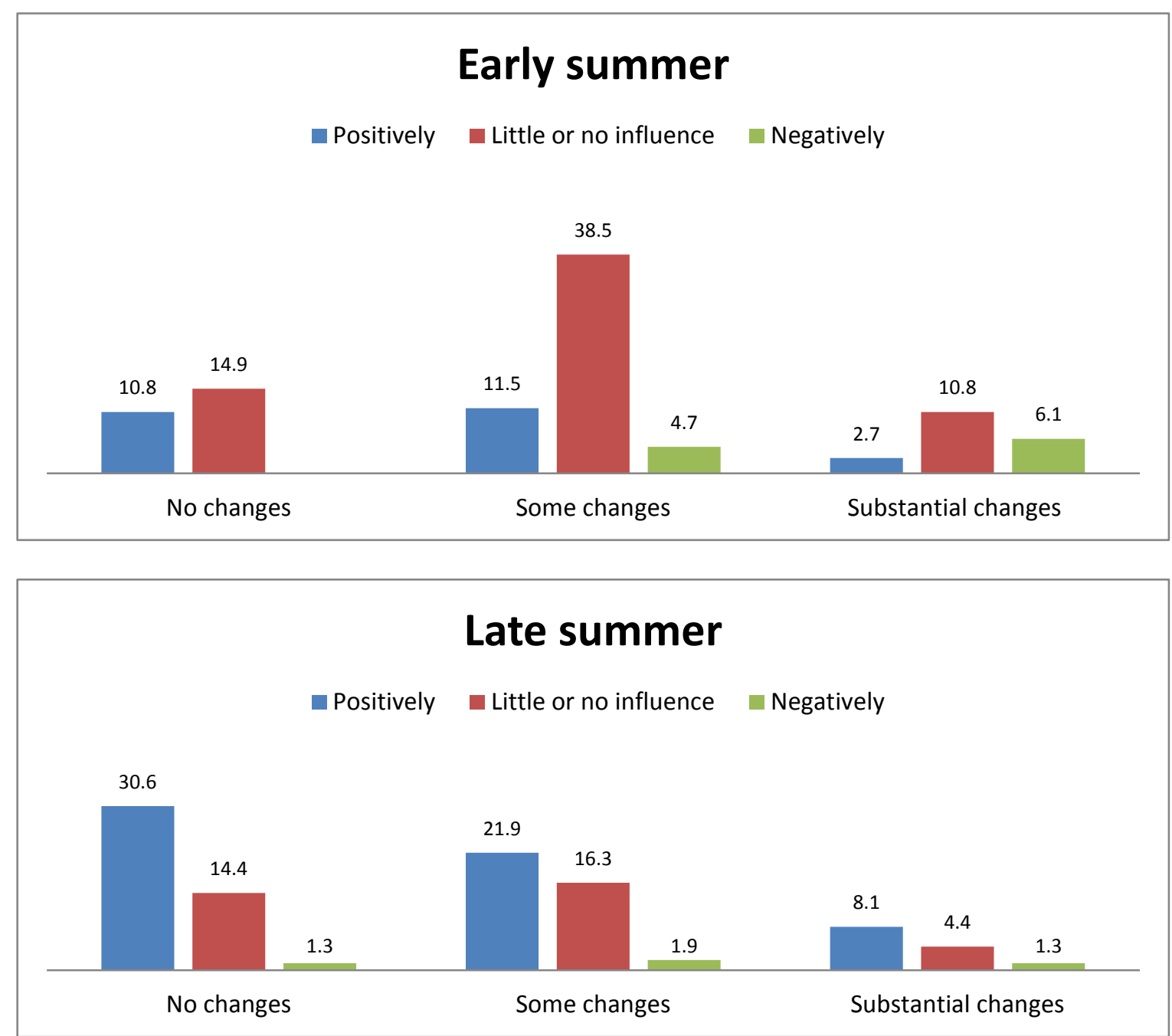

Figure 3. The impact of weather on satisfaction by travel change group ('no change', 'some change', 'substantial change') and survey period (\%). 


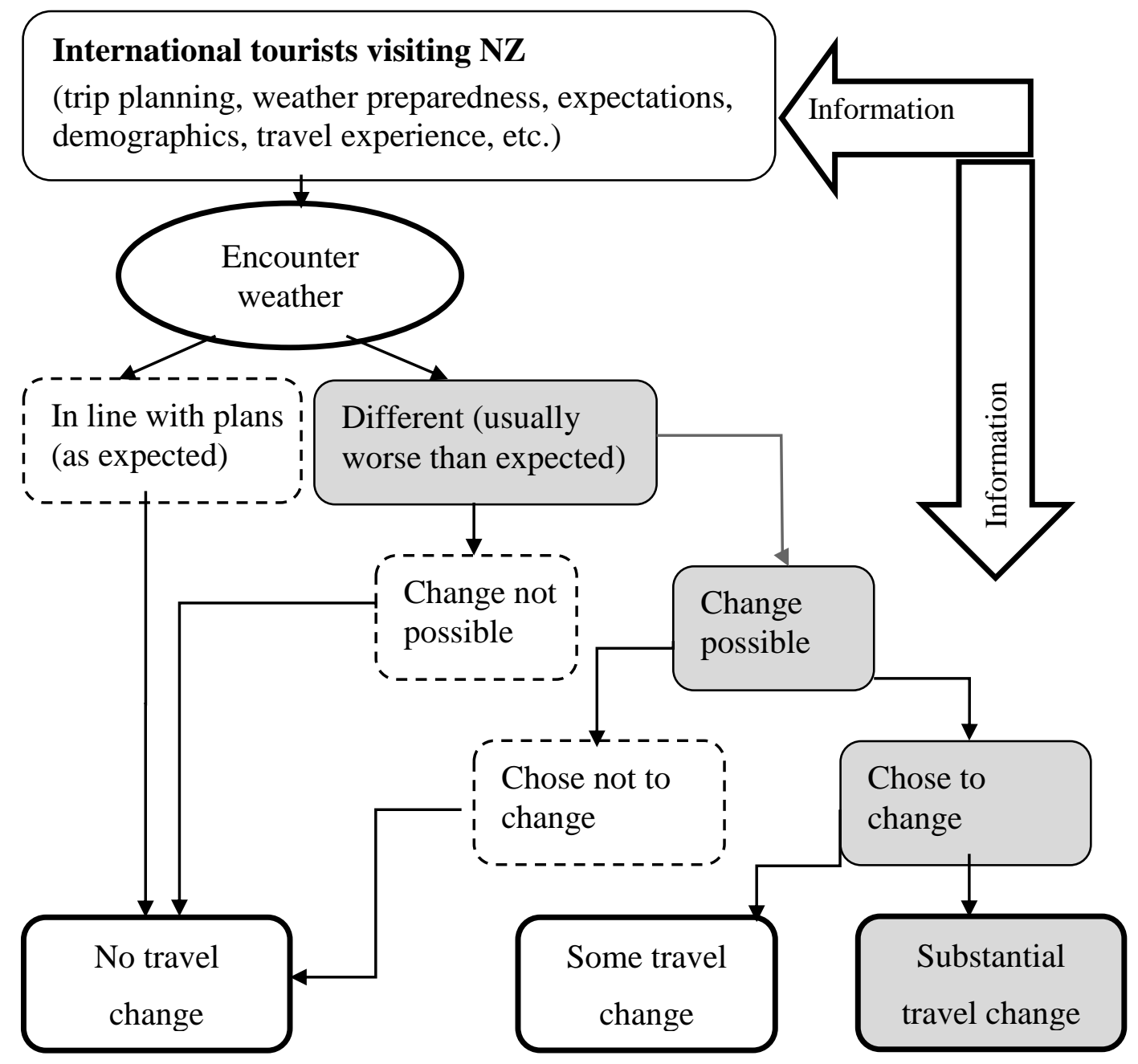

Figure 4. Conceptual framework for tourist adaptation to weather. 